\title{
PENERAPAN MODEL PROBLEM BASED LEARNING UNTUK MENINGKATKAN KEMAMPUAN BERPIKIR KRITIS SISWA KELAS IV DI SEKOLAH DASAR
}

\author{
Suryadin Hasyda ${ }^{1}$, Arifin ${ }^{2}$ \\ Program Studi PGSD \\ ${ }^{12}$ Universitas Muhammadiyah Kupang \\ suryadinhasyda92@gmail.com, adjenawa@gmail.com
}

\begin{abstract}
The aim of this study is to improve students' critical thinking skills through a problem based learning model in class IV SDN Ende 1. The type of research used in this study is classroom action research consisting of several interrelated cycles and the model chosen in this study is a Kemis and Mc Tagart model which consists of several stages namely planning, action, observation and reflection, where actions and observations are carried out together. The subjects of this study were 21 students in class $I V$ SDN Ende 1. Based on the results of data analysis in classroom action research shows that the learning feasibility by applying the learning model Problem Based Learning has increased namely $81.5 \%$ in the first cycle and $94 \%$ in the second cycle, therefore it can be said that the learning process has been carried out very well and in accordance with the reference in the lesson plan that has been made. While the results of observations of student activities during learning by applying model of problem based learning have increased, which is proved by the increase in the average score of student learning activities in the first cycle by 55\% and the second cycle by $87 \%$. This improvement shows that during the learning process students were actively involved in solving problems. The results of the students' critical thinking ability test of the first cycle can be seen that, there are 9 students or $43 \%$ who reach the KKM standard, while 12 students or $57 \%$ do not reach the value of 70 in accordance with the minimum completeness criteria set by the school. While the second cycle is known that as many as 21 students $(100 \%)$ have succeeded and reached the indicator of critical thinking. The highest score obtained by student is 90 and the lowest score is 70 with an average value of $80 \%$ in the critical category. Therefore, the implementation of research by applying the problem based learning model ends in the second cycle. So, through research that has been done, by applying the Problem Based Learning model it is proven that it can improve the critical thinking skills of class $I V$ students whose critical thinking test results are complete or meet the minimum completeness criteria (KKM).
\end{abstract}

Keywords: Problem Based Learning, Critical Thinking Ability.

\section{Pendahuluan}

Pendidikan mempunyai peran yang sangat penting bagi perkembangan suatu bangsa. Kualitas pendidikan suatu bangsa dipengaruhi oleh beberapa faktor, antara lain kurikulum, guru atau tenaga pengajar, fasilitas, dan sumber belajar. Pendidikan harus dikembangkan secara terus menerus sesuai dengan perkembangan zaman. Menghadapi berbagai perubahan di era globalisai saat ini, diperlukan sumber daya manusia agar mampu mengatasi berbagai tantangan yang timbul. Pendidikan abad 21 ini pengetahuan merupakan landasan utama dari segala aspek kehidupan. Peningkatan pengetahuan tidak akan lepas dari dunia pendidikan, karena pendidikan merupakan jalur utama menuju masyarakat yang berpengetahuan. Pendidikan adalah usaha sadar dan terencana untuk mewujudkan suasana belajar dan proses pembelajaran agar peserta didik secara aktif mengembangkan potensi dirinya untuk memiliki kekuatan spiritual keagamaan, pengendalian diri, kepribadian, kecerdasan, akhlak mulia, serta keterampilan yang diperlukan dirinya, masyarakat, bangsa dan negara (pasal $1 \mathrm{UU}$ RI No. 20 tahun 2003 tentang Sistem Pendidikan Nasional).

Tidak bisa dipungkiri bahwa kurikulum mempunyai kedudukan yang sangat penting dalam lembaga pendidikan, yaitu sebagai salah satu penentu keberhasilan pendidikan. Oleh sebab itu untuk menindaklanjuti permasalahan tersebut, pemerintah melalui kementrian pendidikan dan kebudayaan telah melakukan upaya nyata untuk meningkatkan kualitas pendidikan di Indonesia. Bentuk upaya tersebut dapat dilihat dengan adanya pengembangan kurikulum yaitu dari kurikulum KTSP menjadi kurikulum 2013. Pengembangan kurikulum 2013 merupakan langkah lanjutan dari Kurikulum Berbasis Kompetensi (KBK) 
pada tahun 2004 dan Kurikulum Tingkat Satuan Pendidikan (KTSP) pada tahun 2006 yang mencakup ranah kognitif, afektif dan psikomotor secara terpadu. Menurut Peraturan Pemerintah RI Nomor 13 tahun 2015 perubahan kedua atas PP No 19 tahun 2005 tentang standar Nasional Pendidikan tertulis bahwa "Kurikulum adalah seperangkat rencana dan pengaturan mengenai tujuan, isi dan bahan pelajaran serta cara yang digunakan sebagai pedoman penyelenggara kegiatan pembelajaran untuk mencapai tujuan pendidikan". Terkait dengan hal tersebut, Hamalik (2001, p. 28) mengemukakan yang dimaksud dengan pembelajaran adalah suatu proses perubahan tingkah laku melalui interaksi dengan lingkungan, baik dengan guru maupun unsurunsur pembelajaran lain. Sedangkan menurut UU Nomor 20 Tahun 2003 pasal 1 ayat 20 "Pembelajaran adalah proses interaksi peserta didik dengan pendidik dan sumber belajar pada suatu lingkungan belajar". Untuk menciptakan pembelajaran yang membuat siswa aktif, kreatif, efektif dan menyenangkan guru harus merancang perangkat pembelajaran yang didalamnya ada pendekatan, model, metode yang dapat memberikan kesempatan kepada siswa untuk berperan aktif dalam proses pembelajaran di kelas.

Kegiatan pembelajaran di kelas hendaknya seorang guru tidak hanya menyampaikan materi pelajaran, tetapi guru memerlukan sebuah desain strategi pembelajaran yang melatih kemampuan siswa untuk berpikir kritis, mengutamakan struktur kognitifnya secara penuh dan terarah. Untuk dapat membangun keterampilan berpikir kritis siswa, guru harus memberikan pengalaman belajar dengan mendesain proses pembelajaran. Guru mendesain pembelajaran dengan memberikan permasalahan yang dapat meningkatkan kemampuan berpikir siswa dan melibatkan proses menganalisis berdasarkan masalah yang sebenarnya. Proses belajar mengajar yang hanya menyampaikan informasi akan membuat siswa kehilangan motivasi dan konsentrasinya. Proses belajar mengajar adalah melatih siswa untuk berpikir, sehingga kemampuan berpikir tersebut akan menghasilkan siswa yang cerdas dan dapat memecahkan setiap persoalan yang dihadapinya. Dalam sistem pembelajaran guru bisa berperan sebagai perencana (planer) atau desainer (designer) pembelajaran, sebagai implementator dan atau mungkin keduanya (Sanjaya, 2011, p. 15). Hal ini memotivasi guru untuk membiasakan diri pada kegiatan yang bersifat inovatif dan konstruktif bersama siswa. Secara eksplisit kita sering mendengar bahwa pembelajaran harus bersifat konstruktif, dalam artian membangun kompetensi dan potensi siswa. Oleh karena itu, guru tidak hanya membatasi diri pada peran pemberi pengetahuan saja, tetapi juga mendorong pertumbuhan potensi diri siswa yang sejalan dengan penanaman pengetahuan. Untuk itu asumsi yang memposisikan diri sebagai pusat pengetahuan perlu ditinggalkan, dan berupaya membangun proses pendidikan yang kolaboratif dan dialogis dimana siswa menjadi pusat pembelajaran.

Mengajar merupakan aksi mengkompilasi berbagai kompetensi yang selalu menjadi bagian dari figur guru sebagai pendidik. Guru perlu memiliki empat kompetensi dasar yakni pedagogik, profesional, sosial dan kepribadian (Pidarta, 2007, p. 19). Untuk itu, dalam pembelajaran guru mendorong dan memotivasi dirinya untuk mampu memperlihatkan keempat kompetensi ini sebagai bagian dari aktivitas belajar bersama siswa. Dalam proses pembelajaran guru mempunyai peran yang sangat penting untuk meningkatkan kualitas pembelajaran di dalam kelas. Untuk meningkatkan kualitas pembelajaran, guru dapat melakukan pembelajaran yang inovatif, dimana siswa sebagai pusat pembelajaran sehingga pembelajaran lebih bermakna. Kegiatan pembelajaran bermakna memerlukan sebuah desain strategi model pembelajaran yang dapat meningkatkan kemampuan siswa untuk berpikir dan menjadikan siswa sebagai pembelajar yang mandiri.

Problem based learning merupakan model pembelajaran yang melibatkan siswa secara aktif mendorong siswa untuk belajar memecahkan masalah. Aiman (2018) mengemukakan bahwa dimana pembelajaran berbasis masalah adalah suatu model pembelajaran yang dikembangkan untuk membantu siswa dalam mengembangkan 
keterampilan intelektual, berpikir kritis dan menuntut siswa untuk berpartisipasi dalam tim. Model problem based learning ini menempatkan tanggung jawab pada siswa untuk mengakses dan mencari informasi baik individu maupun secara kelompok untuk mencapai tujuan dalam pembelajaran, guru hanya bertindak sebagai monitor.

Berdasarkan uraian di atas dan untuk mencapai tujuan itu, maka materi keragaman suku bangsa dan agama di Negeriku merupakan materi yang sangat berperan penting bagi kehidupan siswa. Materi ini membahas tentang keragaman suku yang terdapat di masyarakat, sehingga dapat mendukung tercapainya pembelajaran yang bermakna bagi siswa. Perpaduan antara materi keragaman suku bangsa dan agama di Negeriku dengan pembelajaran berbasis masalah merupakan perpaduan yang sangat tepat, utamanya di tengah-tengah masyarakat yang hidup di era global dengan suku dan budaya yang pluralistik.

Keragaman suku di Indonesia telah menunjukan bahwa bangsa Indonesia merupakan suatu negara yang multi etnis yang saling melengkapi, bahkan mampu untuk saling menyesuaikan diri dalam kehidupan sehari-hari. Keragaman suku bangsa dan agama merupakan tantangan sekaligus peluang bagi masyarakat Indonesia. Apabila tidak dikelola dan ditangani dengan tepat maka keragaman tersebut dapat mendorong lahirnya persaingan dan perpecahan. Sebagai peluang, keragaman suku bangsa dan agama jika dibina dan diarahkan secara tepat, maka akan menjadi suatu kekuatan atau potensi dalam melaksanakan pembangunan bangsa dan negara Indonesia. Oleh sebab itu paradigma pendidikan multikultur secara implisit menjadi salah satu komitmen pasal 4 UU No. 20 tahun 2003 tentang Sistem Pendidikan Nasional. Dalam pasal itu dijelaskan bahwa pendidikan diselenggarakan secara demokratis, tidak diskriminatif dengan menjunjung tinggi HAM, nilai keagamaan, nilai budaya, dan kemajemukan bangsa.

Secara faktual, kebanyakan guru menerapkan strategi pembelajaran tanpa memahami esensi materi dan memperhatikan karakteristik siswa. Masih banyak guru menggunakan strategi yang menempatkan dirinya sebagai sentral pembelajaran. Fenomena ini tentu bertolak belakang dengan tujuan kurikulum 2013 yang lebih menekankan pembelajaran terpusat pada siswa, siswa dituntut untuk belajar secara aktif, mandiri dan mencari hal-hal yang berkaitan dengan materi yang dipelajari.

Permasalahan tersebut juga terjadi di Sekolah Dasar Negeri Ende 1 yang terletak di Kecamatan Ende Utara, Kabupaten Ende, Provinsi Nusa Tenggara Timur. Peneliti menemukan permasalahan dalam kegiatan pembelajaran yang membuat siswa tidak tertarik dalam menerima informasi yang disampaikan guru. Hal tersebut dikarenakan proses pembelajaran yang masih bersifat tradisional (konvensional) dan berpusat pada guru. Dengan kata lain, siswa hanya dibuat tercengang oleh guru dalam menjelaskan materi pelajaran. Hal ini menyebabkan siswa kurang perhatian dan fokus terhadap apa yang disampaikan guru, dimana sebagian besar siswa tampak mengantuk dan bermalasmalasan. Dengan menerapkan model problem based learning, siswa akan dilatih untuk mampu mengidentifikasi masalah, memecahkan masalah dan membuat kesimpulan. Kegiatan-kegiatan inilah yang akan meransang daya pikir siswa.

Berdasarkan pengamatan pada siswa kelas IV SD Negeri Ende 1 Proses pembelajarannya hanya terpusat pada guru, sehingga daya ingat atau menyimpan informasi yang diperolehnya lemah dan hasilnya tidak memuaskan atau tidak sesuai dengan KKM yang telah ditentukan di sekolah (nilai KKM 70). Hal itu dilihat dari 21 anak yang mengikuti pelajaran, ada 12 siswa yang tidak tuntas. Oleh karena itu, guru dituntut untuk lebih kreatif dalam memilih metode yang sesuai dengan materi yang mampu menciptakan suasana pembelajaran yang efektif dan menyenangkan untuk dapat meningkatkan kualitas pembelajaran. Salah satu cara yang dapat dilakukan adalah dengan menerapkan model pembelajaran yang praktis dan efektif. Berdasarkan permasalahan, kenyataan dan harapan yang telah diuraikan di atas, maka perlu dilakukan penelitian tentang "Penerapan Model Problem Based Learning untuk Meningkatkan Berpikir Kritis Siswa Kelas IV di Sekolah Dasar. 


\section{Metode}

Peneltian ini merupakan penelitin tindakan kelas (PTK) atau Classroom action research (CAR). Penelitian tindakan kelas adalah penelitian yang dilakukan oleh guru di dalam kelasnya sendiri melalui refleksi, dengan tujuan untuk memperbaiki kinerja sebagai guru sehingga kemampuan berpikir siswa menjadi meningkat (Aqib, 2012, p.25). Secara etimologis, ada tiga istilah yang berkaitan dengan penelitian tindakan kelas (PTK), yakni penelitian, tindakan dan kelas. Pertama, penelitian adalah adalah suatu proses pemecahan masalah yang dilakukan secara sistematis, empiris dan terkontrol. Sistematis dapat diartikan sebagai proses yang runtut sesuai dengan aturan tertentu. Artinya proses penelitian harus dilakukan secara bertahap dari mulai menyadari adanya masalah sampai proses pemecahannya melalui teknik analisis tertentu untuk ditarik kesimpulan. Hal ini berarti suatu kerja penelitian tidak dilakukan secara acak, akan tetapi dikerjakan melalui rangkaian proses yang sesuai dengan kaidah-kaidah berpikir ilmiah. Empiris mengandung arti bahwa kerja penelitian harus berdasarkan pada data-data tertentu. Proses pengambilan kesimpulan tidak didasarkan pada khayalan imajinatif peneliti, akan tetapi harus didukung dan didasarkan adanya temuan data dan fakta. Sedangkan terkontrol artinya suatu kerja penelitian harus didasarkan pada prosedur kerja yang jelas, sehingga kita dapat membuktikan hasil temuan yang diperoleh. Kedua, tindakan dapat diartikan sebagai perlakuan tertentu yang dilakukan guru. Dengan demikian, dalam PTK bukan didorong hanya sekedar ingin tahu sesuatu, akan tetapi disemangati oleh adanya keinginan untuk memperbaiki kinerja untuk mendapatkan hasil belajar yang lebih baik. Ketiga, kelas menunjukan pada tempat proses pembelajaran berlangsung. Ini berarti PTK dilakukan di dalam kelas dalam keadaan situasi dan kondisi yang nyata tanpa direkayasa. Desain rancanagan dalam penelitianan tindakan kelas ini menggunakan model Kemmis dan McTaggart terdiri dari empat tahap yaiu perencanaan (planing) pelaksanaan (action), pengamatan (observation) dan refleksi (reflection) dan dilaksanakan dalam bentuk siklus. Pada penelitian tindakan kelas (PTK) komponen pelaksanaan dan pengamatan menjadi satu kesatuan karena dalam penerapan keduanya tidak dapat dipisahkan. Artinya ketika kita melakukan pelaksanakan (action) disaat yang bersamaan pengamatan (observation) juga akan dilakukan hingga tujuan penelitian ini terpenuhi. Data yang di ambil dalam peneltian ini adalah data keterlaksanaan pembelajaran dengan menerapkan model problem based learning dan data hasil tes kemampuan berpikir kritis siswa. Berikut ini adalah desain penelitian tindakan kelas model Kemmis dan McTaggart.

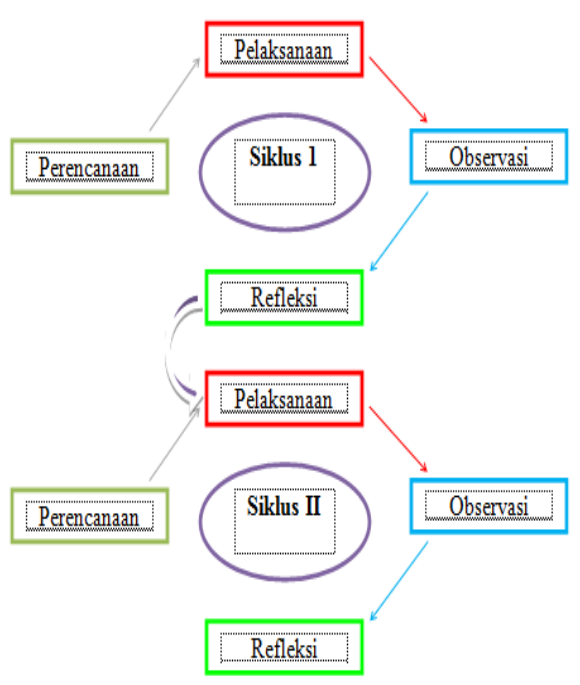

\section{Gambar desain penelitian tindakan model Kemmis dan McTaggart}

Teknik pengumpulan data dalam penelitian yaitu: Teknik obervasi, teknik tes, dan teknik penyebaran angket. Instrumen yang digunakan dalam penelitian ini adalah instrumen penilaian kualitas perangkat pembelajaran yakni lembar validasi perangkat pembelajaran, lembar observasi untuk memperoleh data keterlaksanaan pembelajaran dan hasil tes kemampuan berpikir kritis siswa. Teknik analis data yang digunakan adalah prosentasi ketercapaian hasil tes kemampuan berpikir kritis siswa dan aktivitas siswa selama menerapkan model problem based learning. Data tes keterampilan berpikir kritis siswa diperoleh berdasarkan data skor tes keterampilan berpikir kritis. Nilai keterampilan berpikir kritis siswa dapat dihitung dengan menggunakan rumus: 
Keterampilan Berpikir Kritis = $\frac{\text { Jumlah skor yang diperoleh }}{\text { Jumlah skor selurwhnya }} \times 100$

Kriteria Kemampuan berpikir kritis siswa dapat dilihat pada tabel berikut ini.

\begin{tabular}{ll}
\hline \multicolumn{1}{c}{ Rentangan } & \multicolumn{1}{c}{ Keterangan } \\
\hline $00 \%-20,3 \%$ & Sangat Tidak Kritis \\
\hline $20,4 \%-40,7 \%$ & Kurang Kritis \\
\hline $40,8 \%-61,1 \%$ & Cukup Kritis \\
\hline $61,2 \%-80,5 \%$ & Kritis \\
\hline $81,6 \%-100 \%$ & Sangat Kritis \\
\hline
\end{tabular}

Data hasil pengamatan aktivitas siswa selama kegiatan berlangsung menggunakan presentase. Data aktivitas siswa dapat dihitung dengan menggunakan rumus:

$P=\frac{\Sigma R}{\Sigma N} \times 100 \%$

Presentase aktivitas siswa dalam penelitian ini dapat dilihat pada tabel dibawah ini:

\begin{tabular}{ll}
\hline \multicolumn{1}{c}{ Interval Skor } & \multicolumn{1}{c}{ Kategori Penilaian } \\
\hline $76 \%-100 \%$ & Sangat baik \\
$56 \%-75 \%$ & Baik \\
$26 \%-55 \%$ & Cukup baik \\
$0 \%-25 \%$ & Tidak baik \\
\hline
\end{tabular}

Adaptasi dari Purwanto (2009:101)

Aktivitas siswa yang dinilai dalam penelitian ini meliputi menyimak pelajaran, kerjasama, menghargai pendapat teman, berani presentasi hasil, mengajukan pertanyaan, menjawab pertanyaan, aktif selama pembelajaran berlangsung.

\section{Hasil Dan Pembahasan}

Hasil dan Pembahasan siklus I dan siklus II.

Keterlaksanaan pembelajaran dan akativitas siswa selama proses pembelajaran dengan menerapkan model problem based learning diamati dan ditulis hasil pengamatannya didalam lembar pengamatan oleh dua orang observer. Secara ringkas data hasil keterlaksanaan dan aktivitas siswa dalam pembelajaran dengan menerapkan model problem based learning dipaparkan pada tabel berikut ini.
Tabel 1. Hasil keterlaksanaan pembelajaran dan aktivitas siswa pada siklus I dan II.

\begin{tabular}{llcc}
\hline No & \multicolumn{1}{c}{ Instrumen } & \multicolumn{2}{c}{ Keterlaksanaan } \\
\cline { 3 - 4 } & & Siklus I & Sikus II \\
\hline L. & Hasil observasi keterlaksanaan pembelajaran & $81,5 \%$ & $94 \%$ \\
\hline 2. & Hasil observasi aktivitas siswa & $55 \%$ & $87 \%$ \\
\hline
\end{tabular}

Data keterlaksanaan pembelajaran dan aktivitas siswa diperoleh dengan observasi selama pembelajaran berlangsung. Berdasarkan tabel 1 diatas bahwa penilaian pengamat diperoleh nilai keterlaksanaan pembelajaran siklus I $81,5 \%$ dengan kategori baik dan siklus II 94\% kategori sangat baik. Sedangkan aktivitas siswa pada siklus I 55\% dengan kategori cukup baik dan siklus II 87\% sangat baik, nilai yang diperoleh selalu meningkat di setiap siklusnya. Selanjutnya peneliti juga menyajikan dalam bentuk diagram berikut ini.

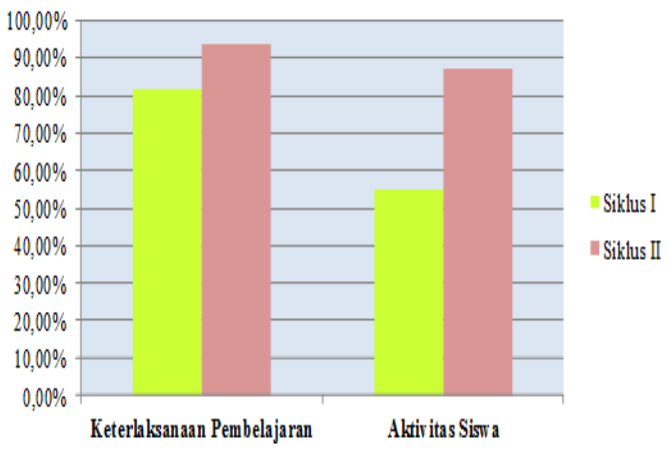

Diagram 1. Hasil Keterlaksanaan Pembelajaran dan Aktivitas Siswa

Dari diagram diatas, terlihat bahwa keterlaksanaan pembelajaran dan aktivitas siswa selalu mengalami peningkatan disetiap siklusnya. Sehingga dapat ditarik kesimpulan bahwa model problem based learning dapat meningkatkan aktivitas keterlaksanaan pembelajaran dan aktivitas siswa telah mencapai indikator keberhasilan dan meningkat setiap silkusnya. Hal tersebut menunjukan bahwa aktivitas guru dan siswa dalam problem based learning sudah baik.

\section{Kemampuan berpikir kritis siswa pada siklus I dan II}

Setelah kegiatan pembelajaran berlangsung, diketahui bahwa siswa dapat menambah pengalaman yang lebih dibandingkan dengan pembelajaran yang hanya menggunakan metode ceramah/ konvensional. Pada kegiatan inti, guru 
membagikan soal untuk mengukur kemampuan berpikir kritis siswa setelah melakukan pembelajaran dengan menerapkan model problem based learning. Semua siswa tampak serius dalam mengerjakan soal yang diikuti oleh 21 siswa pada siklus I dan siklus II. Setelah semua siswa selesai mengerjakan, guru menutup pembelajaran kemudian memberi salam. Skor hasil tes kemampuan berpikir kritis siswa pada siklus I dan II dapat dilihat pada tabel berikut ini:

\begin{tabular}{|c|c|c|c|}
\hline \multirow[t]{2}{*}{ No } & \multirow[t]{2}{*}{ Nama Siswa } & \multicolumn{2}{|c|}{ Nilai } \\
\hline & & Siklus I & Siklus II \\
\hline 1. & Azan A. Satoro & 65 & 80 \\
\hline 2. & Muhamad Awaludin & 70 & 90 \\
\hline 3. & Anggun Putri Zuliana & 50 & 70 \\
\hline 4. & Ardiansya & 60 & 75 \\
\hline 5. & Arini Maharani & 70 & 85 \\
\hline 6. & Avril S. Ayudias & 55 & 70 \\
\hline 7. & Ilmi Safira & 50 & 75 \\
\hline 8. & Liani Aulia Sahara & 75 & 90 \\
\hline 9. & Marchar Yuda & 60 & 80 \\
\hline 10. & Mandala Aditia Saputra & 70 & 85 \\
\hline 11. & Muhamad Rahman & 50 & 70 \\
\hline 12. & Muhammad A.Salam & 70 & 90 \\
\hline 13. & Muhamad Ramadan & 50 & 80 \\
\hline 14. & Muhammad F.B & 60 & 80 \\
\hline 15. & Mochama U. F & 75 & 85 \\
\hline 16. & Muhammad Ulumando & 60 & 75 \\
\hline 17. & Muhammad Farid Saleh & 70 & 85 \\
\hline 18. & Muhammad Fahrizal & 50 & 70 \\
\hline 19. & Muhamad Ismail & 55 & 75 \\
\hline 20. & Natasya P. Difani & 70 & 85 \\
\hline 21. & Nurhayati & 70 & 85 \\
\hline Jum & lah siswa yang mencapai KKM & 9 & 21 \\
\hline & Ketuntasan belajar klasikal & 43 & 100 \\
\hline & $\sum$ Rata-rata & $62,1 \%$ & $80 \%$ \\
\hline & Kategori & $\begin{array}{l}\text { Cukup } \\
\text { Kritis }\end{array}$ & Kritis \\
\hline
\end{tabular}

Berdasarkan tabel diatas diketahui bahwa kemampuan berpikir kritis siswa secara klasikal untuk siklus I belum tercapai yaitu 43 dengan nilai $\Sigma$ Rata-rata $62,1 \%$ dengan kategori cukup kritis. Sedangkan siklus II kemampuan berpikir kritis siswa secara klasikal diperoleh $100 \%$ dan nilai Srata-rata $80 \%$ dengan kategori kritis dan sudah tercapai KKM yang ditentukan di sekolah tersebut. Terlihat adanya peningkatan kemampuan berpikir kritis siswa pada siklus II dengan menerapkan model problem based learning. Secara ringkas tes kemampuan berpikir kritis siswa dapat dilihat pada diagram di bawah ini.

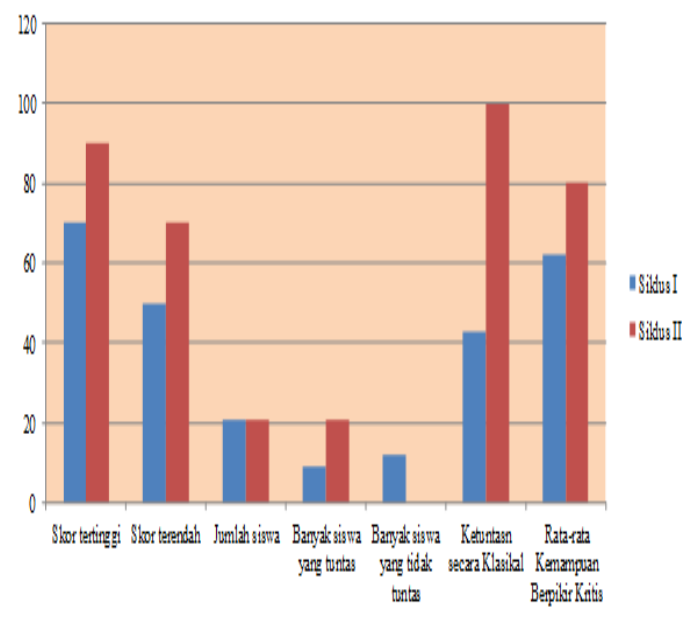

Diagram 2. Hasil Tes Kemampuan Berpikir Kritis Siswa Siklus I dan II

Berdasarkan diagram diatas, hasil tes kemampuan berpikir kritis siswa pada siklus I skor tertinggi 70 , skor terendah 50 , dengan jumlah siswa 21, banyak siswa yang tuntas 9 orang, ketuntasan belajar klasikal 43, dan nilai rata-rata $62,1 \%$. Sedangkan siklus II diketahui bahwa sebanyak 21 siswa (100\%) sudah berhasil memenuhi kriteria kemampuan berpikir kritis. Nilai tertinggi yang diperoleh siswa adalah 90 dan nilai terendah 70 dengan nilai rata-rata $80 \%$ dengan kategori kritis. Oleh sebab itu, pelaksanaan perbaikan siklus ini dapat diakhiri pada siklus II. Jadi, melalui penelitian yang telah dilakukan dengan menerapkan model problem based learning, terbukti dapat meningkatkan kemampuan berpikir kritis siswa kelas IV yang hasil tesnya tuntas atau memenuhi KKM yang ditentukan.

\section{Pembahasan}

Tujuan dari Penelitian Tindakan Kelas (PTK) untuk dapat meningkatkan kemampuan berpikir kritis siswa dengan menerapkan model problem based learning, data pada bagian tes kemampuan berpikir kritis siswa diatas jelas bahwa tujuan PTK ini tercapai sesuai yang diinginkan. Pencapaian tujuan PTK ini baru terjadi pada siklus ke II, oleh karena siklus I masih ada kegiatan siswa yang belum terlaksana dengan baik, yaitu berkaitan dengan kurang terbiasanya siswa dengan model yang diterapkan sehingga banyak siswa yang bingung dan kurang terampil dalam melaksanakan diskusi. 
Kekurangan tersebut kemudian diperbaiki di siklus ke II dan berhasil.

Berdasarkan hasil penelitian yang dilakukan oleh peneliti menunjukan bahwa nilai rata-rata tes kemampuan berpikir kritis siswa untuk siklus I $62,1 \%$, sedangkan nilai rata-rata tes kemampuan berpikir kritis siklus II sebesar $80 \%$. Pembelajaran dengan menerapkan model problem based learning di Kelas IV menunjukkan peningkatan hasil tes kemampuan berpikir kritis siswa. Hal ini membuktikan bahwa model problem based learning merupakan model pembelajaran yang baik dan berpusat pada pelajar yang memberdayakan peserta didik untuk melakukan penelitian, mengintegrasikan teori dan praktik, dan menerapkan pengetahuan dan keterampilan untuk mengembangkan sesuatu masalah yang ditetapkan (Savery, 2006). Oleh sebab itu seorang guru harus memilih model yang sesuai dengan materi yang akan diajarkan pada siswa. Model pembelajaran yang baik, sebaiknya mampu membuat siswa aktif dalam proses pembelajaran bukan sebaliknya.

Pembelajaran melalui model problem based learning memberikan pengaruh positif karena model problem based learning berbantuan media gambar yang dapat memicu kreatifitas dan kemampuan berpikir siswa betul-betul dioptimalisasikan melalui proses kerja kelompok atau tim yang sistematis, sehingga siswa dapat memberdayakan, mengasah, menguji, dan mengembangkan kemampuan berpikirnya secara berkesinambungan. Sehingga dapat meningkatkan kerja sama dan kekompakan dalam anggota kelompok dan menghilangkan kejenuhan saat proses pembelajaran sedang berlangsung.

\section{Kesimpulan}

Berdasarkan rumusan masalah dan hasil penelitian yang telah dibahas sebelumnya, maka dapat ditarik kesimpulan sebagai berikut:

Kesatu, Penerapan model problem based learning materi keragaman suku bangsa dan agama di Negeriku di Kelas IV SDN Ende 1 dapat meningkatkan aktivitas dalam proses pembelajaran, baik itu aktivitas guru maupun aktivitas siswa dalam mengikuti rangkain pembelajaran. Hal ini terjadi karena dalam penerapan model problem based learning sudah terlaksana dengan baik.

Kedua, Penerapan model problem based learning dapat meningkatkan kemampuan berpikir kritis siswa. Hal ini dibuktikan dengan meningkatnya presentase kemampuan berpikir kritis siswa pada setiap siklusnya. Dilihat dari hasil tes kemampuan berpikir kritis siklus I dan siklus II, dimana sebanyak 21 siswa (100\%) tuntas dan memenuhi kriteria kemampuan berpikir kritis. Nilai tertinggi yang diperoleh siswa adalah 90 dan nilai terendah 70 dengan nilai rata-rata $80 \%$ dengan kategori kritis dan telah memenuhi kriteria ketuntasan minimal (KKM) yaitu 70. Oleh karena itu, pelaksanaan penelitian tindakan ini dapat diakhiri pada siklus II.

\section{Daftar Pustaka}

Aiman, Ummu. (2018). Pengaruh Model Pembelajaran Berbasis Masalah Terhadap Literasi Sains dan Berpikir Kritis Siswa Kelas IV di Kota Kupang. Jurnal Ilmiah Pendidikan Citra Bakti.

Arends, R. I. (2012). Learning to Teach. Ninth Edition. United States: Central Connecticut Satate University.

Aqib, Z. (2012). Penelitian Tindakan Kelas untuk Guru. Bandung: Yrama Widya.

Baret, T. (2005). Understanding Problem Based Learning. www.aishe.org/readings/20052/chapter2.pdf.

Dilekli, Yalcin. (2017). The Relationships Between Critical Thinking Skills and Learning Styles of Gifted Students. European Journal of Education Studies. Vol 3, No 4. Pp 69-96.

Ernst, Julie \& Monroe, Martha. (2004). The Effects of Environment Based Education on Students Critical Thinking Skills and Disposition Toward Critical Thinking. Journal Environmental Education Research. Vol 10, No 4. Pp 101-122.

Fathurrohman, M. (2015). Model-model Pembelajaran Inovatif. Jogjakarta: ArRuzz Media

Hamalik, Oemar. (2001). Proses Belajar Mengajar. Jakarta: Bumi Aksara.

Kurniasih, Imas. (2015). Ragam Pengembangan Model Pembelajaran 
untuk Meningkatkan Profesionalitas Guru. Jogjakarta: Kata Pena.

Pidarta, Made. (2007). Wawasan Pendidikan. Surabaya: Unesa University Press

Purwanto, N.2007. Model-model Pembelajaran Mengembangkan Profesionalisme Guru. Jakarta: PT Rajagrafindo Persada.

Rubiah, Musriadi. (2016). Implementation of Problem Based Learning Model in Concept Learning Mushroom as a Result of Student Learning Improvement Efforts Guidelines for Teachers. Journal of Education and Practice. Vol 7, No 22. $\mathrm{Pp} 26-30$.

Sanjaya, Wina (2011). Strategi Pembelajaran Berorientasi Standar Proses Pendidikan. Jakarta: Kencana Prenada Media Grup.
Savery, R. John. (2006). Overview of Problem-based Learning: Definitions and Distinctions. Interdisciplinry Journal of Problem Based Learning. Vol 1, No 1. Pp 12-18.

Snyder, J. Mark. (2008). Teaching Critical Thinking and Problem Solving Skills. The Delta Pi Epsilon Journal. Vol 1, No 2. Pp 90-99.

Sudjono, A. (2005). Pengantar Statistik Pendidikan. Jakarta: Raja Grafindo Persada 